\title{
CORTICOSTEROID BRUISING
}

\author{
BY \\ H. F. WEST \\ Sheffield Centre for the Investigation and Treatment of Rheumatic Diseases, \\ Nether Edge Hospital, Sheffield
}

Unprovoked bruising and excessive bruising following only moderate trauma has become, in recent years, a familiar complication of prolonged corticosteroid therapy. Nashelsky and Smyth (1958), reviewing the subject, showed that the lesions were not due to altered capillary fragility or to a clotting defect. Scarborough and Shuster (1960) studied biopsy material from "corticosteroid purpura" and showed that at the site of the lesions there was a loss, and a disorganization, of dermal collagen.

At a recent corticotrophin conference the opinion was expressed that this pathological bruising did not occur in corticotrophin-treated patients (West, 1960). The purpose of this paper is to substantiate this opinion and to discuss the implications.

Patients.-During the last year 58 patients at one particular follow-up clinic who satisfied the following requirements were examined for evidence of pathological bruising:

(1) They were suffering from rheumatoid arthritis or ankylosing spondylitis without any complicating disease of note.

(2) They had been receiving corticosteroid therapy for at least 2 years at a mean dose level of $7 \cdot 5$ mg. prednisolone or more, or an equivalent dose of triamcinolone or dexamethasone.

or

(3) They had been receiving daily injections of corticotrophin gel for at least 2 years at a clinically effective dose level confirmed by repeated urinary assays for total 17-hydroxycorticosteroid $(17(\mathrm{OH}) \mathrm{CS})$.

\section{Criteria of Pathological Bruising}

(1) Multiple bruises of the senile purpuric type, seen typically on the forearms; and/or

(2) Multiple unprovoked bruises taking 3 weeks or more to clear; also in some cases

(3) Excessive bruises to moderate trauma on the legs or feet, with blood blister formation leading to breaks in the skin and ulcers.

\section{Results}

The findings in the 58 patients are shown in Table I.

TABLE I

FINDINGS IN 58 PATIENTS

\begin{tabular}{|c|c|c|c|c|c|}
\hline \multirow{3}{*}{ Treatment } & \multirow{3}{*}{$\begin{array}{c}\text { No. } \\
\text { of } \\
\text { Cases }\end{array}$} & \multicolumn{4}{|c|}{ Pathological Bruising } \\
\hline & & \multicolumn{2}{|c|}{ Present } & \multicolumn{2}{|c|}{ Absent } \\
\hline & & No. & Per cent. & No. & Per cent $\stackrel{?}{?}$ \\
\hline Corticosteroids & 40 & 24 & 60 & 16 & 40 \\
\hline Corticotrophin & 18 & 0 & 0 & 18 & 100 \\
\hline Total & 58 & 24 & & 34 & \\
\hline
\end{tabular}

The influence of sex, age, duration of disease, duration of therapy, dosage, etc., have been analysed as follows:

(1) Sex and Age Distribution.-The results are shown in Table II.

TABLE II

INCIDENCE OF BRUISING, BY AGE AND SEX

\begin{tabular}{|c|c|c|c|c|c|}
\hline \multirow{2}{*}{ Treatment } & \multirow{2}{*}{ Sex } & \multicolumn{2}{|c|}{ Pathological Bruising } & \multicolumn{2}{|c|}{ Age (yrs) } \\
\hline & & No. & Per cent. & Mean & Range \\
\hline \multirow{4}{*}{ Corticosteroids } & \multirow{2}{*}{ Female } & Present 20 & 83 & $48^{*}$ & $30-65$ \\
\hline & & Absent 4 & 17 & 42 & $30-60$ \\
\hline & \multirow{2}{*}{ Male } & $\overline{\text { Present } 4}$ & 20 & $56 \frac{1}{2}$ & $52-61$ \\
\hline & & Absent 16 & 80 & $48 \frac{1}{2}$ & $33-70$ \\
\hline Corticotrophin & $\begin{array}{c}\text { Female } \\
\text { Male }\end{array}$ & $\begin{array}{l}\text { Absent } 8 \\
\text { Absent 10 }\end{array}$ & $\begin{array}{l}100 \\
100\end{array}$ & $\begin{array}{l}42 \\
41 \frac{1}{2}\end{array}$ & $\begin{array}{l}38-49 \\
19-57\end{array}$ \\
\hline
\end{tabular}

* Six of the affected females were under $\mathbf{4 0}$ years of age. 
(2) Duration of Disease.-In affected females the mean duration was $15 \frac{1}{2}$ years, and in the unaffected females 13 years. In affected males the mean duration was $12 \frac{1}{2}$ years, and in the unaffected it was 12 years.

(3) Duration of Therapy. - In affected patients (all on corticosteroids) the mean duration was $5 \frac{1}{2}$ years; in unaffected patients on corticosteroids it was also $5 \frac{1}{2}$ years, and in those on corticotrophin it was $4 \frac{1}{2}$ years.

(4) Mean Dosage in Last 2 Years. - In the corticosteroid group, the mean dose (as prednisolone) was $10 \mathrm{mg}$. for the affected and $9.3 \mathrm{mg}$. for the unaffected. In the corticotrophin group the mean dose (as 17(OH)CS excreted daily) was $22 \mathrm{mg}$.

(5) Disease Activity and Physical State.-Between the affected and unaffected groups of females there was little difference if any in respect of mean erythrocyte sedimentation rate, haemoglobin, strength of grip, blood pressure, weight, or functional capacity. The mean total white blood count in the affected group was 10,600 and in the unaffected 7,750 . It did appear that patients with the most severe and damaging leg bruising had higher total white counts $(11,000$ 14,000 ) and had received more corticosteroid than the mean for the group.

(6) Adrenal Suppression and Corticosteroid Therapy. -The adrenal output of cortisol (hydrocortisone) can be assessed by measuring the urinary excretion of total $17(\mathrm{OH}) \mathrm{CS}$ and deducting the contribution made, if any, by the dose of exogenous corticosteroid.

The mean adrenal contribution to $17(\mathrm{OH}) \mathrm{CS}$ in thirteen affected patients was $5 \cdot 3 \mathrm{mg}$. (range $2 \cdot 5-9$ ); in twelve unaffected patients it was $7 \mathrm{mg}$. (range 4-11).

(7) Effect of Change of Therapy.-Three affected women changed from oral corticosteroid to corticotrophin during the period of observation. One stayed on corticotrophin for 1 month and was sure that her "bruisability" decreased. The other two have now been on corticotrophin for more than 6 months and have had no pathological bruises during this time.

\section{Discussion}

There is no doubt about the reality of this striking difference between oral exogenous corticosteroid therapy and corticotrophin therapy, at least at the dose levels used at this Centre. Savage has found the same difference at the West London Hospital (personal communication). The bruising is at times a serious complication when the skin of the leg breaks down, and it cannot be assumed that the skin and subcutaneous tissues are the only connective tissues involved. It is therefore of some importance that the cause and a remedy be found. The defect may be due either to a direct action of the exogenous corticosteroid on the connective tissue, or to the loss of an adrenal hormone or of the adrenocorticotrophic hormone, occasioned by the administration of the exogenous corticosteroid. If an elevated level of circulating cortisol can, in time, cause the pathological bruising, its absence during corticotrophin therapy may be due to the concurrent secretion of a compensating adrenal hormone or of corticotrophin.

If the lesions result from a relative lack of the adrenal androgen, substitution therapy may provide a remedy. This possibility needs investigation. Two of the affected females referred to above received methandrostenolone (Dianabol) $10 \mathrm{mg}$. daily for 6 months without improvement.

\section{Summary}

Over the period of a year, 58 patients receiving long-term corticosteroid therapy for rheumatoid arthritis and ankylosing spondylitis have been examined repeatedly for evidence of pathological bruising. Of forty receiving exogenous corticosteroids, 60 per cent. had pathological bruising and of eighteen receiving corticotrophin none was so affected.

The pathological bruising of long-term exogenous corticosteroid therapy can be a serious complication. (It is hoped that the above findings may provide a clue to its remedy.)

\section{REFERENCES}

Nashelsky, G. M., and Smyth, C. J. (1958). Ann. rheum. Dis., 17, 76.

Scarborough, H., and Shuster, S. (1960). Lancet, 1, 93. West, H. F. (1960). "Proceedings of the Corticotrophin Conference, Sheffield, 1960." (Acta med. scand., Suppl. 352.) Munksgaard, Copenhagen.

\section{Ecchymoses corticostéroìdes RÉSUMÉ}

Pendant un an, 58 malades atteints d'arthrite rhumatismale et de spondylarthrite ankylosante et soumis à un traitement prolongé par des corticostéroïdes, furent examinés à plusieurs reprises en recherchant des ecchymoses pathologiques. On en trouva chez $60 \%$ des 40 malades traités par des corticostéroïdes exogènes, mais on n'en trouva aucune chez les 18 malades restants traités par la corticotropine. 
Les ecchymoses pathologiques peuvent constituer une complication sérieuse de la thérapie prolongée par des corticostéroïdes exogènes.

\section{Equimosis corticosteroides}

Sumario

Durante un período de un año, 58 enfermos con artritis reumatoide y con espondilartritis anquilosante, sometidos a terapéutica de larga duración con corticosteroides, fueron repetidamente examinados para comprobar la presencia o ausencia de equimosis patológicas. De 40 enfermos tratados con corticostercides exogenos, un 60 por ciento presentó equimosis patológicas, ỵ? entre 18 tratados con corticotropina ninguno fué afectado de esta manera.

Las equimosis patológicos en tratamiento a largeo plazo con corticoesteroides exogenos pueden ser una complicación seria.

\section{UNIVERSITY OF TORONTO}

A new rheumatic diseases unit has been formed within the Department of Medicine in the University of Toronto with Dr. Wallace Graham, F.R.C.P., as Director.

As well as the present divisions at Sunnybrook Veterans Hospital and the Toronto General Hos- pital, a new thirty-bed long-stay active treatmenop. division has been established at the Queen Elizabetho Hospital, Toronto. It is hoped to expand research $\bar{Q}$ facilities in the connective tissue diseases.

Dr. Graham is President of the Pan-American League against Rheumatism. 